\title{
RUMO À TEORIZAÇÃO ALÉM DO ESTADO: O DUPLO PROCEDIMENTO DE DESNATURALIZAÇÃO E TEMPORALIZAÇÃO ${ }^{1}$
}

\author{
Diego Santos Vieira de Jesus
}

\begin{abstract}
RESUMO
Este artigo tem como objetivo explicar por que um duplo procedimento de desnaturalização e temporalização oferece um primeiro passo rumo a uma teorização que aponte para a dissolução das noções de autoridade e identidade do conceito de Estado e a redefinição do problema da ordem política internacional, bem como identificar, nos debates recentes da teoria política e da teoria de Relações Internacionais, abordagens alternativas que sigam na direção desse duplo procedimento. A hipótese central cuja correção pretende-se verificar é a de que o duplo procedimento de desnaturalização e temporalização permite a desestabilização simultânea das segmentações internas que fortalecem o Estado e que o diferenciam como locus de autoridade contraposto a forças apolíticas da sociedade doméstica, e das divisões externas, que o distinguem de entidades internacionais similares. A partir dessa desestabilização, problematizam-se interpretações estatistas de autoridade, e redefinem-se discussões sobre a ordem política internacional, gerando-se novas matrizes e renovando-se o entendimento do político: organizações alternativas do espaço podem ser pensadas a partir da apreciação da diferença como meio de auto-reflexão e crítica social, bem como se pode chegar a perspectivas que considerem incoerências e ambivalências das práticas estatais e questionem o controle do Estado sobre espaços e corpos na busca de preservação de seu status ontológico e prático.
\end{abstract}

PALAVRAS-CHAVE: Teoria Política; Teoria de Relações Internacionais; teoria pós-moderna; Estado; desnaturalização; temporalização.

\section{INTRODUÇÃO}

Ao conceber que o discurso moderno controverte a autoridade, mas circunscreve esse questionamento, Jens Bartelson (2001) procurou elucidar que o conceito de Estado exerce uma função constitutiva dos discursos político e científico modernos e torna-se parte nãoproblematizada da reflexão política a partir de iniciativas de sua própria contestação e redefinição. A conservação da autoridade virtual e simbólica do Estado repousa no seu próprio desvelo, permitido pelo espírito crítico da modernidade; particularmente pela sua problematização sistemática e pela incorporação de sua negação ao discurso: a crítica caracteriza-se como uma seqüência de transgressões discursivas motivadas pela proibição da contestação à autoridade, e a presença simbólica do Estado no discurso age

\footnotetext{
1 Agradecemos ao apoio do Conselho Nacionald e Desenvolvimento Científico e Tecnológico (CNPq), que concedeu ao autor uma bolsa de doutorado.
}

como principal condicionante da realização de tais questionamentos. Para fortalecer-se como fonte de autoridade, o Estado revigora o silêncio sobre suas fundações ao expor sua superfície às críticas. Nesse sentido, o conceito de Estado - cujas predisposições são reforçadas em vez de minadas pelos críticos - é compreendido não apenas empiricamente como objeto focal da pesquisa científica, mas transcendentalmente como condicionante do conhecimento autônomo e considerado "científico".

$\mathrm{O}$ ataque pluralista dos teóricos da interdependência complexa (KEOHANE \& NYE, 1977) e dos analistas que deram destaque ao processo de formulação das decisões de política externa (SNYDER, BRUCK \& SAPIN, 1961) problematizou o valor analítico de tal conceito, mas acabou por meramente substituí-lo por equivalentes semânticos que traziam soluções estatais para questões políticas. O Estado determinado na sua dependência de forças socioeconômicas e na aptidão de conciliar essas realidades - foi posteriormente reposicionado no 
foco analítico com autonomia suficiente para explicar os pré-requisitos de reprodução da ordem capitalista; porém, a indivisibilidade da autoridade política foi preservada, naturalizando-se segmentações Estado-sistema internacional e Estado-sociedade. Mais recentemente, a desnaturalização do Estado a partir de fora estratégia retórica que destitui a simplicidade fundacional da distinção entre Estado e sistema internacional como "natural" ou "dada" e concebea como um artifício cultural -, e a temporalização a partir de dentro - estratégia retórica que questiona a aparente imutabilidade da segmentação entre Estado e sociedade civil -, viabilizaram, a partir de críticas imanentes, a reconstrução da história do conceito de Estado como definidor da própria modernidade política. Porém, foram incapazes de isoladamente "dissolver" o Estado e repensar as condições gerais de autoridade: num procedimento de fora para dentro, a desnaturalização dos aspectos externos da condição de Estado preserva a separação entre Estado e sociedade e não lida com os fatores que tornam tal segmentação possível; já a temporalização, num movimento de dentro para fora, concebe a distinção entre Estado e sociedade como historicamente contingente, mas a soberania externa é tratada como constante transhistórica que circunscreve o local de temporalização (BARTELSON, 2001, p. 154-155, 183-184).

Tendo em vista que grande parte dos conceitos de ordem política ainda permanece condicionada ao Estado e que os principais questionamentos do conteúdo e da forma da autoridade preservam a fonte dessa mesma autoridade, o objetivo central deste artigo é explicar por que um duplo procedimento de desnaturalização e temporalização oferece um primeiro passo rumo a uma teorização que aponte para a dissolução das noções de autoridade e identidade do conceito de Estado e a redefinição do problema da ordem política internacional. Além disso, busco identificar, nos debates recentes da teoria de Relações Internacionais, abordagens alternativas que sigam na direção desse duplo procedimento. A hipótese central cuja correção pretendo verificar é a de que o duplo procedimento de desnaturalização e temporalização permite a desestabilização simultânea das segmentações internas que fortalecem o Estado e que o diferenciam como locus de autoridade contraposto a forças apolíticas da sociedade civil doméstica, e das divisões externas, que o distinguem de entidades internacionais similares. A partir dessa desestabilização, problematiza-se interpretações estatistas de autoridade, e redefine-se discussões sobre a ordem política internacional, gerando-se novas matrizes e renovando-se o entendimento do político: organizações alternativas do espaço podem ser pensadas a partir da apreciação da diferença como meio de auto-reflexão e de crítica social, bem como pode-se chegar a perspectivas que considerem incoerências e ambivalências das práticas estatais e questionem o controle do Estado sobre espaços e corpos na busca de preservação de seu status ontológico e prático.

Procuro investigar a correção da suposição de que a perspectiva analítica proposta por David Blaney e Naeem Inayatullah (2004) aponta para a desestabilização das segmentações internas e externas que fortalecem o conceito de Estado: o reconhecimento do Outro interno não-conformado ao processo de homogeneização cultural sistemática representa um desafio ao exercício da autoridade do Estado sobre forças sociais numa comunidade cuja coesão e integridade procura preservar, e o compartilhamento de experiências de sofrimento com Outros externos visando à sua superação no pensamento e na prática questiona a rigidez de barreiras externas supostamente imutáveis entre identidade e diferença. Tais iniciativas funcionam como fontes de auto-reflexão e transformação cultural, e estabelecem a conversação entre tradições que respondem à opressão nas "zonas de contato", permitindo pensar formas de organização espacial alternativas às demarcações cristalizadoras do Estado. Examino também a suposição de que a abordagem de Phillip Darby (1998) transcende a rigidez de binarismos essencializados pelas segmentações internas que reificam o Estado a partir da ênfase nos elementos particulares que operam fora das regras de engajamento estipuladas para a relação entre Estado e forças sociais e configuram-se como limites ao exercício efetivo do seu poder, indicando que tais elementos podem também ser fontes de transformação sistêmica. Simultaneamente, tal perspectiva questiona segmentações externas pretensamente dadas ao salientar a cultura simbiótica entre colonizador e colonizado, a heterogeneidade de sentido e o hibridismo, o qual, em vez de se sustentar isoladamente, é colocado em diálogo com perspectivas de comportamento político que 
operam na base de conflitos não somente dentro de sociedades, mas também na interação internacional.

Além disso, busco averiguar a correção da suposição de que a abordagem de Michael Shapiro (2004) avança no sentido da temporalização, pois, enquanto o Estado-nação é concebido pelo autor como um ator biopolítico que traduz o corpo biológico como social e tenta aprisioná-lo num aparato de sujeição que desvela o projeto particular de produção de unidade cultural etnonacional, trabalhos artísticos fora da governança cultural estatal desenvolvem mecanismos alternativos de adesão e questionam a homogeneidade das culturas nacionais e a imutabilidade dos procedimentos estabelecidos para a interação entre Estado e sociedade civil, demonstrando a flexibilidade e a capacidade de transformação dessa segmentação. Simultaneamente, Shapiro desnaturaliza o Estado ao salientar que o conceito de biopoder envolve uma dimensão expansionista e militante voltada para a contenção de ameaças ao Estado no nível internacional, desestabilizando segmentações supostamente dadas entre Estado e sistema internacional ao concebê-las como artifícios flexíveis que operam demarcando a diferença também no nível externo.

Antes de prosseguir à investigação, cabem algumas observações importantes. Primeiramente, cumpre lembrar que a simples consideração da existência de múltiplas identidades e de outras organizações do espaço que convivem com o Estado não necessariamente pressupõe ultrapassar e abandonar uma concepção de fronteira como a ambição reguladora moderna que o conceito de Estado ajudou a cristalizar. Hoje, temos múltiplas formas de construção de territórios no globo terrestre, que vão desde a fixidez e o encaixamento hierárquico dos territórios-zona até a fragmentação e a descontinuidade dos territórios-rede. Porém, o que ressalto é que, mesmo que o sujeito possa hoje construir múltiplos territórios e desenvolver o multipertencimento a experiências espaciais integradas e diversas, isso não necessariamente trará uma superação da noção de fronteira enquanto ambição reguladora, disciplinadora e excludente, cristalizada pelo conceito de Estado: embora falemos em fronteiras diluídas em face das novas tecnologias e do desenvolvimento do ciberespaço ou em múltiplas fronteiras sobrepostas estabelecidas pela globalização ou pelos processos de integração regional, várias dessas fronteiras novas, integradas, fluidas e sobrepostas até mesmo à do Estado ainda prevalecerem demarcando antagonismos, mesmo que não permaneçam onde estavam até então. A demarcação de fronteiras continua a significar a definição de autoridade sobre um espaço, revelando-se que, mesmo que exista maior interação com a diferença presente além das fronteiras nacionais, isso não trouxe necessariamente o engajamento com ela, pois continuamos a perpetuar mecanismos de exclusão desses "Outros" (WALKER, 2005, p. 9). As "novas fronteiras" podem assumir formas alternativas ou difusas, mas continuam a reproduzir uma concepção totalizante que o Estado - enquanto instituição responsável pela organização primordial do espaço no mundo moderno - ajudou a cristalizar. No pensamento e na prática políticos, o conceito de Estado ainda preserva a sua centralidade ao funcionar como ponto de referência e condicionar o próprio pensamento sobre organizações alternativas a ele, autorizando formas alternativas de organização espacial que complementem suas funções sem que minem a sua autoridade, descartando outras que propõem sua superação, abandono ou destruição e circunscrevendo os questionamentos feitos a ele. $\mathrm{O}$ que proponho aqui é que, para pensarmos em outras organizações do espaço que não estejam submissas ao condicionamento estatal, é produtivo primeiramente questionar as fronteiras internas e externas que fortalecem a autoridade estatal - em relação à sociedade civil e ao sistema internacional, respectivamente -, evidenciando sua artificialidade e arbitrariedade. O questionamento do controle que o Estado exerce sobre espaços e corpos pode representar um primeiro passo importante na redefinição de discussões sobre a construção da ordem internacional e, assim, pensar num mundo pós-vestfaliano marcado sim por uma multiterritorialização e identidades distintas, mas no qual a diferença seja considerada como meio de auto-reflexão e crítica social, não como disfunção ou anomalia.

Ademais, o fato de conceber o Estado como uma realidade discursiva não significa necessariamente a desconsideração da presença material e modelar dos aparelhos estatais na vida internacional dos indivíduos, no controle de organizações ou na sistematização de processos comerciais, financeiros e tecnológicos. Um ponto central do argumento é a consideração de que o significado dessa presença material depende de 
uma rede conceitual que constitui a autoridade política, confere indisputabilidade à entidade estatal e atribui-lhe a prerrogativa de controlar recursos e de utilizar legitimamente a violência organizada. Nesse sentido, o reconhecimento da presença material do Estado não conduz necessariamente à sua reificação; porém, o que pode sim levar a tal reificação é a compreensão desse Estado como um fato dado e não-problematizado por sua suposta existência como parte irredutível da realidade internacional, algo que será criticado mais adiante nessa abordagem. Cumpre também observar que, historicamente, cidadãos submeteram-se à realidade material do Estado, e, hoje, ao redor do planeta, existe uma demanda de indivíduos por tal instituição, como os casos de palestinos e curdos exemplificam. Essas são apenas provas da força do conceito que transcende a própria discussão no âmbito da produção do conhecimento: a centralidade assumida pelo Estado fez eom que tal conceito fosse colocado como referência para o entendimento de vários outros, de forma que se desenvolve a perspectiva de que a instituição estatal é a mais habilitada materialmente, inclusive - para garantir a segurança e o bem-estar dos indivíduos, sendo flexível o suficiente na contemporaneidade para conviver com outras organizações espaciais que complementem a sua ação, mas que não necessariamente trarão o seu abandono, minarão completamente a sua autoridade ou romperão com o entendimento de fronteira que ele ajudou a cristalizar. Isso limita a imaginação política, pois 1) instituições alternativas ao Estado que poderiam ser dotadas da capacidade material de preservar o bem-estar desses indivíduos e que garantiriam um verdadeiro engajamento com a diferença são concebidas como utópicas ou ainda dependentes do consentimento estatal para sua operação; 2) relega-se em segundo plano a noção de que o Estado pode ser um dos principais promotores da violência contra seus próprios cidadãos, não funcionando como um espaço coeso numa realidade dada e não-problematizada.

A “teoria de Estado” subjacente ao argumento aqui proposto traz uma crítica à concepção anistórica do conceito. A perspectiva aqui desenvolvida considera esse Estado um conceito que conduz ao exercício de controle sobre indivíduos e recursos em circunstâncias históricas específicas ao ter assumido centralidade no pensamento e na prática políticos em tais circunstâncias e tolhido, assim, o desenvolvimento de concepções alternativas de organização do espaço que minassem completamente a sua autoridade. Ao sinalizar que essa autoridade constrói-se de forma performática e interpretativa - sem necessariamente ignorar a sua presença material -, a abordagem proposta neste artigo desestabiliza o caráter supostamente essencial e fundacional dessa autoridade ao evidenciar suas incoerências e ambivalências, abrindo assim espaço para novas formas de pensamento sobre a organização do espaço sem as amarras do conceito estatal e permitindo a reconsideração da diferença como um meio de autocrítica e de reflexão social, não como um elemento desestabilizador de uma ordem estatal reificada e supostamente dada. Evidentemente, o Estado enquanto instituição jamais desapareceria completa e imediatamente diante da proposição de novas formas de organização do espaço, nem seria ingênuo a ponto de acreditar que as assimetrias materiais geradas por ele podem desaparecer instantaneamente nas dimensões doméstica e internacional. Além disso, não existe garantia de que, ao conduzir tal processo de desestabilização das fronteiras que conferiram a centralidade do conceito, o resultado do empreendimento será bem sucedido ou necessariamente levará ao abandono ou à superação desse Estado tanto na prática política como na produção acadêmica. Porém, um primeiro passo na direção de um pensamento alternativo sobre a organização do espaço de forma a criar zonas de engajamento com a diferença e superar as experiências de sofrimento que a organização estatal promoveu pode ser válido para a reflexão sobre a possibilidade de construção de uma nova ordem internacional que garanta o bemestar e a segurança dos indivíduos.

Após tais considerações, explicitarei na seção seguinte o processo pelo qual o Estado assumiu o status duplo de objeto potencial e de condição do conhecimento, estabelecendo não apenas a história possível e a identidade moderna, mas os parâmetros da discordância teórica, de forma a preservar-se dessas problematizações. Apontarei que, embora as estratégias de desnaturalização e temporalização busquem questionar a autoridade e a identidade do conceito de Estado, elas isoladamente acabam fortalecendo demarcações que conservam tal conceito; porém, teorizações alternativas que realizem simultaneamente essas críticas podem desreificar tal conceito, abrindo 
espaço para o desenvolvimento de novas matrizes ou a indicação de loci alternativos de enunciação do político. Posteriormente, examinarei como as abordagens do mainstream da teoria de Relações Internacionais reificaram o Estado e como as principais críticas feitas ao conceito por grande parte das perspectivas pós-positivistas preservaram a autoridade estatal. Antes de tecer as considerações finais, indicarei que as abordagens de Blaney e Inayatullah (2004), Darby (1998) e Shapiro (2004) apontam para a realização do procedimento duplo de desnaturalização e temporalização ao questionarem delimitações rígidas externas e internas que fortalecem o Estado e, a partir disso, propondo perspectivas alternativas de autoridade e identidade que não estejam restritas de maneira imutável a um Estado supostamente homogêneo. Cumpre lembrar que, embora essa discussão esteja pautada nos termos colocados por Bartelson, ela é apenas uma dentre tantas formas alternativas possíveis de se pensar caminhos para uma teorização que vá além do Estado. Tal autor não será, de forma alguma, situado como um gatekeeper que estipula termos absolutos e únicos para uma discussão no perfil dessa que será aqui apresentada.

\section{O CONCEITO DE ESTADO E OS PROCE- DIMENTOS DE DESNATURALIZAÇÃO E TEMPORALIZAÇÃO}

As "fundações" da autoridade definem-se, segundo Bartelson (2001, p. 7-9), por meio de "mecanismos de esquecimento" de sua origem de maneira que tal autoridade antecede e constitui a comunidade política relacionada a ela - e também organizam as condições de questionamento que garantem sua reprodução. Com enfoque nos modos de enunciação dos argumentos acerca do status ontológico do Estado e nas pressuposições da estrutura conceitual mantida pelos múltiplos discursos estatais, o autor desvela que as críticas compartilham condições de possibilidade com seu objeto: ao admitirem "fundações míticas" da autoidentidade conceitual do Estado como ponto inicial, tais críticas consolidam a presença fundacional do seu alvo. O conceito de Estado definiu parâmetros da discordância teórica sem que fosse sujeito à contestação pela forma como a problematização foi delimitada: a cienticação e o questionamento dessa ambição motivaram o declínio da contestabilidade, já que, embora se pudesse discordar do status ontológico do Estado, dificultava-se a concepção de autoridades além dele sem que esse deixasse de ser um esforço "científico" ou "político".

As fontes da ambigüidade conceitual a partir das quais o Estado assume sua identidade são, para Bartelson (2001, p. 10-25), as práticas de definição - que, no esforço de clarificação do sentido, resultam na reprodução daquilo que se propõem a questionar - e o posicionamento conceitual no discurso: quanto mais central for o conceito, maior é a facilidade de utilizá-lo na definição de outros conceitos e de colocá-lo como fundacional e constitutivo do discurso político moderno. A pressuposição da presença do Estado no discurso político resulta da lógica de centralidade e ambigüidade, condicionando sua identidade conceitual e a própria imaginação política pela diferenciação categórica do Estado quanto às relações interestatais no nível internacional e à sociedade doméstica e orientando questionamentos que reproduzem tal ambigüidade. Transcendendo a tensão entre a necessidade de validação conceitual filosófica e a contextualização historicamente variável dos conceitos, a abordagem conceitualista de Bartelson viabiliza o entendimento do conceito de Estado como entidade discursiva autônoma em relação ao status ontológico de conceitos fora do texto, mas não em relação a outras entidades lingüísticas. Os critérios de coerência e consistência variam no tempo por serem conceituais - preservando a abertura histórica e a possibilidade de julgamento filosófico -, e a história do conceito pode ser traçada em relação a outros conceitos, mas sem que se torne uma abstração ou uma condição transcendental de subjetividade.

Com o objetivo de entender como o Estado despontou como objeto de pesquisa científica mas sem incorrer nas categorias reificadoras da historiografia tradicional, Bartelson salienta a interdependência lógica entre tal conceito e a ciência política, que conquista coerência teórica e identidade discursiva a partir da relevância ontológica oferecida ao Estado, num processo de deslocamento dos atributos do objeto para o campo de conhecimento que mascara problemas da identidade estatal e disciplinar e sinaliza a pressuposição da autoridade no discurso. O Estado assume status duplo, pois, além de objeto potencial de conhecimento, é condição desse conhecimento, integral à definição da história possível e da identidade moderna: justapondo-se o empírico e o transcendental, ele coloca-se não apenas como fenômeno histórico desdobrado no tempo - 
“resultado da evolução"-, mas sua presença como meio trans-histórico dessa evolução torna-se condicionante de passado e presente. Ele posiciona-se como fundacional ao mesmo tempo em que é inscrito como paradigma da ordem política. Organizam-se em categorias transhistóricas comunidades individualizadas dotadas de passados específicos - um "museu vivo" - e encapsula-se a totalidade dessa experiência numa "história universal" que circunscreve ordens políticas históricas no presente (BARTELSON, 2001, p. 30-74; 182-183).

Conceituado como um amálgama historicizado de identidade/comunidade e autoridade a partir de sua diferenciação quanto às entidades internacionais similares e à sociedade civil pela concepção de locus de autoridade contraposto a forças domésticas, o conceito de Estado é aplicado trans-historicamente e opera como ponto de convergência de uma rede conceitual que constitui a autoridade da ciência política, naturalizando demarcações disciplinares e conferindo-lhe indisputabilidade. Tal aplicação relaciona-se à historiografia "presentista” e às aspirações nomotéticas da ciência política ligada à ordem e ao progresso. Oferece, assim, resposta para problemas políticos "eternizados" ao situar o Estado como fonte única de autoridade, possibilitando investigações do passado como se estados sempre estivessem presentes e reforçando a autoridade da ciência na sua identificação com a autoridade estatal (BARTELSON, 2001, p. 65-76).

Uma série de abordagens teóricas de cunho pós-moderno ou pós-estruturalista assumiu o Estado como contingente ao discurso e criticou o uso desse conceito nas perspectivas mais tradicionais. Tais críticos afirmavam que as vertentes dominantes pressupunham o Estado como dado ao conhecimento político. Enquanto há abordagens como a de Rose e Miller (1992) que procuram desestabilizar tal pressuposição pela desconstrução das segmentações entre Estado e sociedade doméstica, outras como as de Ashley (1987) e de Walker (1993) fazem-no a partir do questionamento da demarcação rigorosa entre Estado e sistema internacional. O principal obstáculo a ambos os perfis de abordagem crítica é o fato de que cada forma de crítica ao Estado acaba concebendo como "dado" ou "nãoproblematizado” aquilo que a outra procura questionar. Embora ambas tentem reconceituar o problema da ordem política de forma a desestabilizar noções de autoridade e identidade do conceito de Estado, elas acabam reforçando segmentações que fortalecem tal conceito (BARTELSON, 2001, p. 150-151).

Começando com identidades e modos de autoridade presentes, a desnaturalização desvela que a diferenciação entre Estado e sistema internacional é resultado de hábitos discursivos. Porém, a dissolução do Estado ocorre somente de fora para dentro: ao interpretar-se o Estado como um espaço intermediário entre o doméstico e o internacional e que parece contingente a partir de fora, negligencia-se que tal espaço também seja construído a partir da diferenciação em relação à sociedade doméstica. As condições de possibilidade dessa divisão interna são marginalizadas, tendo em vista que a desnaturalização está voltada para a desconstrução dos aspectos externos da condição de Estado. Já a temporalização procura desfazer mitos de origem ou fundações últimas por meio da relativização histórica da autoridade política ao longo do tempo e revelar a "impureza" da identidade como resultado de forças históricas além do controle da identidade constituída. Ao conceber-se a soberania como ficção jurídicopolítica, a separação entre Estado e sociedade é vista como historicamente mutável, de forma que as instituições estatais são tratadas como expressões de técnicas variadas de governo, não como sua justificativa implícita ou explicação teórica. Contudo, a soberania externa ainda é tratada como constante através da história, o que delimita o espaço de temporalização possível (BARTELSON, 2001, p. 154-155; 168-180).

Embora isoladamente tais estratégias de crítica imanente acabem assumindo aquilo que criticam - as interpretações estatistas de autoridade e identidade -, é possível imaginar teorizações alternativas que conduzam simultaneamente esses procedimentos e, assim, desestabilizem noções reificadas de autoridade e identidade associadas ao Estado, criando novas matrizes ou apontando outros loci de enunciação do político. Enquanto a desnaturalização das demarcações de dentro e fora permite questionar a cristalização da tensão entre ordem e anarquia, a temporalização concomitantemente viabiliza maior ênfase às condições mutáveis que estabelecem padrões de interação entre Estado e sociedade. Mais especificamente, o Estado pode ser considerado uma reivindicação específica do monopólio da violência, o que permite compreendê-lo como uma possibilidade 
contestável cuja realização completa é impossível e cuja legitimidade depende de seu sucesso relativo em vez do contrário. Tal Estado é entendido, assim, como palco de desordem antes de apresentar-se como fonte de identidade e ordem política, evidenciando-se a violência interpretativa de sua autoridade. Ao mesmo tempo, toda política passa a ser concebida como "internacional”, já que a idéia de internacional não mais ocorre numa dimensão pré-dada, mas remete às práticas espaçotemporalmente específicas que estabelecem tal dimensão num processo de busca de supostos princípios políticos primordiais (BARTELSON, 1998, p. 321-322). A ficção jurídico-política do Estado auto-identificado e seu corolário - o sistema internacional - são entendidos, nas palavras de Bartelson (1998, p. 322), como "estabilizações momentâneas das práticas históricas da política de poder”.

O procedimento duplo de desnaturalização e temporalização pode apontar para uma teorização além do Estado na medida em que evidencia que noções supostamente subjacentes ou fundacionais são, na verdade, exercícios de controle interno e externo em circunstâncias históricas específicas. Explicita, assim, que existem entendimentos alternativos de autoridade e identidade que não estão encapsulados de forma imutável num Estado pretensamente coeso e homogêneo. Trazendo à tona as ambivalências na interação com a diferença, não apenas é possível dar-se um primeiro passo na direção da desestabilização das segmentações internas e externas que reificam o Estado, mas apontar para uma renovação do entendimento do político no processo de teorização, que se volte, por exemplo, para a personalização das questões da ordem internacional e para o engajamento com a diferença no nível local e global. Com tal iniciativa, encoraja-se a produção de novos corpos de conhecimento que transcendam o rigor das demarcações internas entre Estado e sociedade civil e externas entre Estado e sistema internacional e que permitam pensar em organizações alternativas do espaço a partir dos impulsos de regeneração e apreciação da diversidade como meio de autoreflexão e crítica social. Além disso, podem desenvolver-se interpretações que questionem a autoridade do local de enunciação dominante, proporcionem a auto-reflexão a partir da consideração de incoerências e alteridades nas práticas estatais e problematizem o controle que 0 Estado exerce sobre espaços e corpos.

\section{O ESTADO E SEUS CRÍTICOS}

Antes de examinar tais caminhos alternativos, cumpre primeiramente explicar por que o mainstream da teoria de Relações Internacionais reificou o Estado, oferecendo um tratamento nãoproblematizado às delimitações internas e externas que cristalizam o conceito, e por que as principais críticas feitas ao conceito contribuíram para conservar a autoridade estatal. Em face à multiplicidade de abordagens nesse debate, seria impossível abarcar a totalidade de autores envolvidos; por isso, serão consideradas obras que apresentaram alguns dos principais parâmetros de discussão teórica na área nos últimos cinqüenta anos. A seleção dessas obras foi feita a partir do tratamento central oferecido por elas em relação a três critérios indicados por Bartelson (1998): indivisibilidade dos estados, distinguibilidade entre eles e continuidade espaço-temporal estatal. A consideração desses elementos permite verificar o processo pelo qual se constrói a acomodação do conceito de Estado numa posição de centralidade para a explicação de outros conceitos não apenas nas obras em foco, mas naquelas que as tiveram como referência ou inspiração. Esses três pontos foram discutidos de forma explícita nas obras consideradas nessa pesquisa, embora estejam também presentes de forma mais sutil ou coadjuvante em produções como as de Morgenthau, Bull, Wallerstein e Onuf. Evidentemente, tal critério de seleção não é isento de questionamento, nem a leitura das obras aqui apresentadas é a única possível. Autores relevantes foram deixados de lado pela própria limitação de espaço, mas a minha expectativa é a de que, a partir da análise aqui feita, estudos futuros possam debruçar-se sobre a centralidade que tal conceito assumiu em outros estudos relevantes na área de Relações Internacionais.

Para Waltz (1979), os estados, vistos como unidades fundamentais de organização política, têm autonomia suficiente em relação a suas sociedades para buscar racionalmente interesses nacionais e são dotados de unidade e capacidade de ação coerente, executando respostas às restrições sistêmicas. Waltz enfatiza o contexto da ação, em que se observa a falta de autoridade central para qual os estados possam apelar por proteção: no meio anárquico marcado pela auto-ajuda, unidades similares na natureza diferem em capacidade e respondem a ameaças tomando ações que 
impeçam o crescimento de poder dos adversários e adotando uma política de equilíbrio sistemicamente induzida, que reduz a violência mas não elimina completamente a incidência de guerra. As mudanças no comportamento desses atores e os resultados no sistema são explicados não com base na variação das características das unidades, mas na mudança na distribuição de capacidades. Para o autor, o entendimento da estrutura do sistema internacional permite explicar padrões de comportamento estatais, pois os estados determinam interesses e estratégias com base nos cálculos de suas posições no sistema. A ligação entre tal estrutura e o comportamento dos atores é dada pela suposição da racionalidade, que permite prever que os líderes responderão aos incentivos e às restrições impostas pelos seus meios (WALTZ, 1979; GRIECO, 1997, p. 165-177).

Ao promover a segmentação entre as relações internacionais e o contexto em que se desenvolvem, Waltz postula generalizações sobre uma lógica supostamente uniforme da ordem internacional, e sua abstração com relação aos desenvolvimentos espaço-temporais específicos impede a consideração de dinâmicas contingentes, com isso limitando a antecipação e a explicação da mudança. Produzindo um regime sobre a "verdade", o autor também marginaliza variações introduzidas nos padrões comportamentais dos estados pelos processos subestatais e pelos indivíduos. Além de invocar a universalidade da ordem política internacional baseada na soberania a fim de cristalizar a separação entre os níveis doméstico e internacional, legitima a inevitabilidade das relações internacionais como zona de conflito (LEBOW, 2007, p. 415-435). O realismo estrutural adquire, assim, coerência e identidade a partir da relevância ontológica atribuída ao Estado, que, além de objeto, é colocado como condição desse conhecimento. Ademais, Waltz reafirma segmentações desse Estado em relação a entidades internacionais funcionalmente semelhantes apontando que a diferenciação entre elas dá-se pela distribuição de capacidades - e a sociedade doméstica, em contraposição à qual tem autoridade e autonomia para responder a desafios políticos eternos. Tratando os critérios de indivisibilidade dos estados, distinguibilidade entre eles e continuidade espaço-temporal estatal como constantes trans-históricas, Waltz concebe tais atributos como inferencialmente conectados e definidos em termos uns dos outros, de forma a conservar tais elementos gerais que caracterizam a condição de Estado - mesmo em face de mudanças na distribuição de capacidades entre estados específicos - e a compreender o Estado como fato bruto e inteligível por sua existência como parte irredutível da realidade internacional. Busca confirmar suposições sobre a essência desse Estado com base numa autoridade supostamente primordial ou fundacional. Ao mesmo tempo, Waltz fortalece a autoridade da sua teoria ao identificála com a autoridade do Estado, já que tal conceito na abordagem neo-realista visa a representar uma realidade política dada, tornando-a acessível ao conhecimento (BARTELSON, 1998, p. 298-302).

Na efervescência intelectual das décadas de 1970 e 1980, diversos ataques ao realismo e ao neo-realismo foram lançados. Grande parte deles incidia sobre o pouco espaço oferecido pelos neorealistas para mudanças sistêmicas proporcionadas pelas unidades, enquanto outros eram voltados para a negação dos grandes níveis de interdependência econômica e a marginalização da política doméstica na definição do comportamento do Estado por tais teóricos. Keohane desafiou a perspectiva de que a anarquia inevitavelmente levava estados ao conflito, primeiramente com o conceito de "relações transnacionais" - que atacava a idéia de um Estado unitário e coeso como unidade de análise - e depois com o “institucionalismo neoliberal”, que defendia que as instituições poderiam superar obstáculos à cooperação. O autor destacou a importância de outros atores no sistema internacional além dos estados - como os subestatais, transestatais e nãoestatais -, numa dinâmica de movimentos sociais complexos que envolvia a formulação da política externa e os processos transnacionais, abarcando as questões de barganha, coalizão e compromisso (GOUREVITCH, 1999). Em vez da interação entre estados unitários preocupados primariamente com a segurança nacional definida em termos militares, Keohane e Nye (1977) viram múltiplas áreas importantes, bem como indicaram a ruptura da hierarquia entre áreas temáticas - as questões militares não eram sempre as dominantes -, a utilidade declinante da força, a importância dos regimes internacionais e a fragmentação da autoridade em cada Estado. Posteriormente, com o desenvolvimento do institucionalismo neoliberal, Keohane passou a compartilhar mais aspectos com os neo-realistas: aceitava a anarquia internacional e o egoísmo racional dos estados, mas mostrava 
que egoístas poderiam cooperar estrategicamente num sistema anárquico e ressaltava a relevância das instituições para se evitarem trapaças.

Elementos como interdependência e regimes internacionais foram acomodados dentro do neorealismo na década de 1980 , ao mesmo tempo em que o neoliberalismo redefiniu-se de uma interdependência complexa para uma versão estatocêntrica mais compatível com o realismo. Houve uma maior aceitação do neo-realismo pela sua compatibilidade, após adaptações, com as perspectivas de escolha racional e a teoria dos jogos, que ganhavam adeptos na área de Relações Internacionais (KAHLER, 1997). Naquele contexto de maior aproximação entre tais abordagens, Keohane (1986) propôs uma perspectiva multidimensional que relaxava suposições do realismo estrutural e apontava para o desenvolvimento de melhores teorias de política doméstica, formulação de decisão e processamento da informação a fim de cobrir o vácuo entre as esferas interna e externa de forma sistemática. Tal programa de pesquisa reteria a parcimônia característica do realismo estrutural e sua ênfase nos incentivos e nas restrições do sistema internacional, adaptando-as para melhor lidar com a realidade contemporânea e com o contexto da ação antes de entender a ação propriamente dita.

Tanto na produção sobre a interdependência complexa como na argumentação do institucionalismo neoliberal, o Estado ainda era situado como fundação da teorização de Keohane, já que condicionava o domínio da objetividade tanto pela permanência da distinção do locus da ordem política internacional como pela introdução de equivalentes semânticos que viabilizavam a continuidade dessa ordem. Keohane compartilhava suposições da tradição política ocidental de centralidade do conceito de Estado, reificando-o: num momento em que o conceito ainda operava como o princípio da identidade disciplinar, tal crítico simplesmente atestava a centralidade discursiva desse conceito. O esforço de reconceituação teórica - como a redução do Estado a componentes mais tangíveis, como os atores subestatais e não-estatais, que questionavam a noção do ator monolítico - enfrentava o dilema de explicar a constituição dessas partes e a interação entre elas e revelava dificuldade de solucionar tal problema sem incorporar o conceito monista do Estado ou algum equivalente lógico
(BARTELSON, 2001, p. 77-113). Era mantida, assim, a ambivalência sobre a fonte de autoridade que preservava a coesão entre grupos e indivíduos. Conforme a produção de Keohane caminhou na direção de um maior estatocentrismo com o institucionalismo neoliberal, reificavam-se ainda mais as distinções entre estados concebidos como egoístas racionais e a anarquia internacional na qual tais unidades poderiam cooperar estrategicamente, bem como entre Estado e atores da sociedade doméstica, que atuavam e interagiam num sistema em que a maior parte dos canais de ação ainda eram definidos por estados.

Nos estudos sobre integração regional, também é bastante evidente a permanência da centralidade do conceito de Estado tanto no processo de teorização como nas aplicações empíricas. Por exemplo, autores como Haas enfocam o ciclo diacrônico da integração regional ao conceberem a convergência de interesses e de expectativas de elites nacionais acerca dos benefícios advindos da integração e a ênfase no papel das instituições supranacionais como meios mais efetivos para a solução de dilemas comuns. Os teóricos neofuncionalistas reconhecem que as barganhas intergovernamentais convencionais representam apenas o mínimo denominador comum e vêem que a competência adequada de uma terceira parte pode mudar as negociações de forma a levar a resultados que representam a conciliação das diferenças. Se a terceira parte tiver poderes formais suficientes, as negociações podem apresentar resultados melhores de interesse comum (KELSTRUP, 1998, p. 29-30). Porém, como sinalizado anteriormente acerca das abordagens de orientação liberal, os neofuncionalistas problematizam a noção do Estado como ator unitário e destacam o papel dos atores sociopolíticos na dimensão interna, mas o Estado coloca-se novamente como condição para se considerar, por exemplo, a explicação da construção e da interação entre esses atores. Além disso, a integração auto-sustentada imaginada por esses autores no caso europeu não ocorreu em face de crises internacionais como as do petróleo na década de 1970, que explicitaram a crença de que o Estado era a instituição mais habilitada a contornar os efeitos deletérios desses impactos. Autores de outras orientações dentro dos estudos sobre Integração Regional examinam formas alternativas de organização do espaço, enfocando perspectivas como "federações de estados" 
(CAMARGO, 2004) ou “ordens neomedievais”, com princípios de territorialidade e soberania sendo substituídos por padrões de identidade e de autoridade em sobreposição (HURRELL, 1995). Herz e Hoffmann (2004, p. 167-175) destacam que a dinâmica dos processos de intensificação em profundidade - extensão de harmonização das políticas - e abrangência - gama de questões inclusas - das relações entre atores pode levar à criação de novas formas de governança políticoinstitucionais de escopo regional e conduzir a uma multiplicidade de resultados institucionais. Porém, a desestabilização dos limites entre o nacional e o internacional trazidas pelos processos de integração regional não significa que a noção de fronteira cristalizada pelo conceito de Estado tenha sido superada enquanto ambição reguladora da vida moderna: ao contrário, as novas fronteiras estabelecidas por tais processos revelam-se altamente flexíveis a ponto de ainda prevalecerem demarcando antagonismos, mesmo que não permaneçam onde estavam até então. A delimitação de fronteiras continua a significar a definição de autoridade sobre um espaço, revelando-se como o discurso moderno limita nossa percepção de que, mesmo que nos engajemos com os "Outros" além das fronteiras nacionais, continuamos a reproduzir práticas de discriminação desses "Outros" (WALKER, 2005, p. 9). Nesse sentido, noções de organização espacial cristalizadas pelo conceito de Estado continuam sendo o parâmetro seguido por tais estudos, e os questionamentos feitos ao conceito são circunscritos de forma a preservar a sua centralidade no processo de teorização.

A proposta mais pragmática das perspectivas racionalistas ia além do neo-realismo e do neoliberalismo ao desenvolver abordagens mais modestas que oferecessem respostas mais precisas às questões do mundo pós-Guerra Fria em vez de formulações teóricas gerais. Porém, tais perspectivas limitaram-se a formular quebracabeças envolvendo atores individualistas e racionalidade instrumental na estrutura de jogos que abarcam idéias de cooperação e conflito (KATZENSTEIN, KEOHANE \& KRASNER, 1998). Embora tenham oferecido uma importante contribuição para uma reformulação mais consistente do mainstream teórico, tais perspectivas contentaram-se em apresentar novas reflexões e novos pontos focais de estudo, como a intensidade de competição e cooperação com a verificação de hipóteses testáveis; a importância das normas e regras e seus efeitos sobre recompensas; a distribuição de informação e as vinculações entre áreas temáticas, que trabalham com a maior incidência de problemas de barganha na cooperação. Continuaram, assim, a conceber o Estado como elemento fundacional e paradigma da ordem política internacional ou, mantendo-se as suposições estatistas, simplesmente substituíram o Estado por atores mais tangíveis como grupos domésticos ou formuladores de decisão oficiais, que tomavam decisões calculadas em nome do Estado ou comportavam-se como os atores unitários das abordagens anteriores.

Embora grande parte do ataque pós-positivista buscasse questionar o compromisso do mainstream com uma visão de ciência unificada e a adoção de metodologias das ciências naturais para explicar o mundo social, tais perspectivas também acabaram preservando, por diferentes razões, a autoridade do Estado. Wendt (1992; 1999) verifica que identidades são relacionais e que os atores definem seus interesses nos processos de definição da própria situação. Numa teoria sistêmica socializada como a proposta pelo autor, identidades e interesses não resultam da anarquia de forma lógica ou causal ou são elementos essenciais da anarquia, mas são socialmente construídos. Com ênfase nos processos sociais de interação e aprendizado, Wendt esclarece que as estruturas sociais não apenas regulam o comportamento, mas constroem identidades e interesses, de forma que o conhecimento que os define é endógeno à interação. Tais estruturas da associação humana são primariamente culturais em vez de fenômenos materiais, de forma que o significado de forças materiais e o conteúdo dos atores dependem das idéias compartilhadas nas quais estão envolvidos. $\mathrm{Na}$ visão de estrutura relacional de Wendt, os atores agem dentro de certa lógica e, por meio de sua ação no processo, podem problematizar e mudar essa lógica. Assim, enquanto Waltz desenvolve uma teoria da recorrência marcada por um claro determinismo estrutural, Wendt diz que, na construção de uma teoria social que inclua a interação e a co-constituição entre agente e estrutura, a recorrência do sistema de estados dáse por meio das idéias e a mudança é possível, pois os agentes podem transformar a realidade por meio da prática. O agente não só é construído pela estrutura, mas é construtor do mundo numa concepção que busca superar a impessoalidade e 
o determinismo do estruturalismo tradicional e as limitações inerentes ao individualismo metodológico.

Enquanto para Waltz a composição dos estados é semelhante e suas características são dadas, é possível para Wendt haver formas estatais diferenciadas como resultados de processos distintos de construção social. Os estados são vistos por Wendt (1999) como atores corporativos, entidades auto-organizáveis cujas estruturas internas conferem capacidades para ação coletiva institucionalizada. As identidades permitem a mobilização de fatores culturais, materiais e intelectuais que dão capacidade de ação a esse Estado, concebido como ator organizacional inserido em uma ordem institucional-legal propriedade marxista do Estado-como-estrutura -, que o constitui com soberania e monopólio do uso legítimo da violência organizada - propriedades weberianas do Estado-como-ator - sobre uma sociedade - propriedade pluralista do Estadocomo-sociedade - num território. Tal ator é présocial em relação a outros estados e pode ter diversos interesses baseado em múltiplas identidades que variam cultural e historicamente; porém, compartilha com outros atores semelhantes propriedades essenciais em virtude de sua identidade corporativa como Estado, tendo interesses intrínsecos e generalizáveis como sobrevivência física, autonomia, bem-estar econômico e auto-estima coletiva (idem, p. 233238).

Embora reconheça que as segmentações entre Estado e sociedade e entre Estado e sistema internacional são socialmente construídas e que a indivisibilidade, a distinguibilidade e a continuidade espaço-temporal que identificam o Estado são condições cuja aplicabilidade varia com o contexto histórico (BARTELSON, 1998, p. 305), Wendt (1999, p. 203-214) não problematiza a idéia de que tal Estado é o locus supremo de autoridade política pautada numa estrutura organizacional unificada e não-rivalizada em face das divisões internas, nem questiona a noção de que o Estado é o responsável pela manutenção da ordem - o que envolve a reprodução das condições domésticas de construção da sociedade, particularmente a coincidência entre as fronteiras e as políticas do Estado e as fronteiras e as necessidades de grupos pré-existentes sob seu controle (idem, p. 210-211) - e pela proteção da integridade dessas condições em relação a outros estados. Além de reificar a centralidade do Estado no estudo das Relações Internacionais, Wendt (idem, p. 208-209; 243-244) recai no essencialismo ao conceber o Estado como um ator homeostático dotado de propriedades, motivações e interesses intrínsecos aproximando-se da visão individualista de que o Estado é ontologicamente anterior ao sistema de estados (idem, p. 198-199) - e reconhece que, ao buscar generalizações acerca de propriedades trans-históricas desses atores, concebe em tais aspectos os estados como exógenos ao sistema e que agente e estrutura não são mutuamente constitutivos na sua totalidade.

Com base no materialismo histórico, Cox (1986; 1993) aplicou conceitos gramscianos às relações internacionais e desenvolveu uma visão da política global na qual forças sociais, estados e ordens mundiais são aspectos organicamente relacionados da realidade social, historicamente produzida por processos em que as relações materiais e os auto-entendimentos sociais estão profundamente interligados. Assim, vê os homens como produtores das formas históricas de vida e fornece elementos para a transformação da realidade, estando atento ao compromisso com a emancipação. Em relação ao Estado, Cox vê-lo como construção histórica, permitindo pensá-lo como monopolizador da força coerciva e espaço em que o consenso deve ser exercido participação de instituições, intelectuais etc. Embora o autor aponte os riscos de reduzir-se a vida social, política e material nas relações internacionais às relações interestatais, as mudanças na ordem internacional estão ligadas às transformações do Estado e a como isso se reflete nas ordens, instituições e forças que o mantêm. Na atualidade, Cox vê a transformação do Estado a partir da rearticulação das forças produtivas e da internacionalização do capital. A práxis liga política e economia, estrutura e agente, liberdade e necessidade, surgindo dessa ligação a necessidade de emancipação. É também notório o desafio do autor à rígida separação analítica entre ordem doméstica e internacional - "ortodoxa como a divisão entre economia e política” -, que pode servir como um dispositivo que fragmenta a realidade de forma a obscurecer a relação orgânica entre as experiências global e local. O argumento do autor é o de que a Teoria Crítica é, assim, holística, ligando questões de ordem moral, autoridade e justiça às questões de eficiência, de 
forma que nem a sociedade nem o mercado são redutíveis um ao outro. Contudo, mesmo gozando de autonomia apenas relativa, o Estado - e não o modo de produção ou a estrutura de classes derivados dele - ainda é fundamental para a preservação da coesão da ordem política e a resolução do antagonismo entre classes (BARTELSON, 2001, p. 145), de modo que Cox acaba também por reificar tal conceito.

Já Walker (1993; 2005) apontou para a possibilidade de desestabilização de categorias mutuamente constitutivas entre dentro e fora e a implementação da crítica às práticas logocêntricas modernas de oposição binária. $\mathrm{O}$ autor desvela que, dentro do "Internacional Moderno", a preservação da integridade soberana foi possível a partir do estabelecimento de uma hierarquia em circunstâncias espaço-temporalmente específicas, na qual o sujeito moderno coloca-se como centro interpretativo soberano, uma "realidade maior e privilegiada" ou uma "presença nãoproblematizada”, e o "Outro", concebido em referência a tal centro, é compreendido como uma negação dessa identidade e objetificado num processo de produção do exterior pelo sujeito. Simultaneamente, o "Internacional Moderno" remete a uma articulação espaço-temporalmente específica das relações entre estados soberanos como expressões de povos e culturas particulares e do sistema internacional como uma expressão da humanidade universalmente concebida. A partir disso, desenvolvem-se a incorporação e a subjetivação do mundo ao "mundo do moderno" e a exclusão de "outros mundos", apontando-se para uma indicação específica das opções políticas e filosóficas que devem ser reconhecidas, definindo-se claros limites à capacidade de levarem-se em conta outras possibilidades. A modernidade é estabelecida como uma "forma cultural específica” (WALKER, 2005, p. 4), segmentada de outras formas espaço-temporais específicas de vida num segundo processo de exclusão: cria-se um “exterior” à produção de subjetividade moderna, de forma que suposições modernas sobre soberania e sistema internacional - marcadas pela marginalização e depreciação da diferença - asseguram sua continuidade por fortalecerem a ausência de elementos "nãomodernos" (idem, p. 4-6).

Embora tenha desnaturalizado o Estado concebendo-o como artifício discursivo, a abordagem de Walker sobre as distinções condicionantes de sua possibilidade apresenta claras limitações. O Estado é compreendido como articulação historicamente específica da relação entre a universalidade e a particularidade no tempo e no espaço, que soluciona o problema constante da comunidade política; contudo, embora o procedimento de desnaturalização proposto por Walker pressuponha a desestabilização dos binarismos responsáveis pela arbitrariedade de arquiteturas que constituem o Estado em oposição ao sistema internacional, a dissolução do Estado é conduzida a partir de fora, não de dentro. Apesar de compreender o Estado como uma abstração localizada entre as dimensões interna e externa, Walker não problematiza o entendimento desse espaço como segmentado da sociedade civil, preservando tal distinção e as condições de sua possibilidade intocadas. Nesse sentido, ao não desestabilizar a separação entre Estado e sociedade doméstica, traz-nos de volta às fundações da autoridade política: o Estado parece contingente a partir de fora, mas a segmentação entre Estado e forças internas que o torna possível ainda é preservada no núcleo do conceito. Não é possível afirmar que Walker conceba uma suposta inevitabilidade do Estado por sua pretensa natureza universal ou dada, mas tal Estado persiste como conceito central na sua obra ao reforçar-se sua presença fundacional na imaginação política (BARTELSON, 2001, p. 167-169).

\section{RUMO À TEORIZAÇÃO ALÉM DO ESTADO}

Embora tais perspectivas teóricas tenham incorrido na reificação do Estado, uma série de abordagens críticas vem apontando possíveis caminhos para uma teorização que vá além desse conceito, desestabilizando as segmentações internas e externas que cristalizam o Estado e redefinindo o entendimento do político e da própria área de Relações Internacionais. Em vez de encapsularem a diversidade em categorias de um centro interpretativo soberano que macula visões culturais do Outro, Blaney e Inayatullah (2004) trazem à tona a inabilidade das Relações Internacionais na oferta de respostas criativas à diferença - ainda vista pelas abordagens tradicionais como "ameaça” ou "disfunção" - e propõem a reimaginação crítica das origens e do perfil da área como teoria sobre relações interculturais a partir de uma perspectiva etnológica. A diferença é concebida como recurso 
de auto-avaliação capaz de transformar visões do Eu com relação ao Outro e à sua própria cultura no "momento etnológico" todoroviano. Abalizado no potencial de "autodescoberta cultural" de Nandy, o diálogo cultural viabiliza a desestabilização de tendências polarizantes que objetificam as diferenças interna e externa. Tal iniciativa proporciona respostas aos desafios da interação com a diversidade por meio da auto-reflexão e da aliança entre críticas sociais culturalmente diversas à desigualdade. Nesse sentido, as Relações Internacionais redefinem-se como um campo de conhecimento heterológico a partir do tratamento das ambigüidades geradas na interação com a diferença e da exploração das possibilidades alternativas das "zonas de contato" psicológico e social, particularmente do diálogo potencial que colabora para a elucidação mútua das culturas. Ao se abandonar a busca por uma ordem isomórfica com a "provincialização" das Relações Internacionais, os particularismos da experiência ocidental com a diferença e do processo histórico de delimitação espaço-temporal de fronteiras rígidas são desvelados a fim de se transcender sua hegemonia (BLANEY \& INAYATULLAH, 2004, p. 7-17).

Ao invés de conceberem um espaço doméstico não-problematizado marcado pela homogeneidade e pela imutabilidade de delimitações naturalizadas entre a autoridade estatal e forças domésticas, Blaney e Inayatullah apontam na direção da desestabilização das segmentações internas que reificam o Estado ao captarem que a diferença político-cultural foi entendida no processo de construção dos estados modernos como elemento desestabilizador da harmonia interna. Por isso, tentou-se gerenciá-la com hierarquia, erradicação, assimilação ou expulsão na “cruzada interna” pela unidade da comunidade política estatal. Atenta-se, assim, para as condições suscetíveis à transformação que estabelecem os padrões de interação entre Estado e sociedade, além de se ressaltar a pluralidade presente numa dimensão doméstica que antes se supunha homogênea e coesa, com o destaque à presença de forças históricas não-conformadas à autoridade estatal. Os autores salientam que, embora se esperasse que a diversidade fosse administrada na dimensão doméstica e que a construção de uma "diferença internacionalizada" pudesse resolver o "problema” ao negociarem-se regras para o relacionamento entre comunidades políticas, tal resposta hierarquizante e disciplinadora restringe o reconhecimento dos Outros internos e a apreciação do Eu como parte do Outro além das fronteiras. A violência perpetua-se com relação às minorias nãoconformadas dentro dessas unidades, e desestabiliza-se a idéia essencializada do Estado como a autoridade provedora de segurança de uma sociedade civil supostamente homogênea (BLANEY \& INAYATULLAH, 2004, p. 21-28; 32-45).

Concomitantemente, a soberania externa desse Estado não é tratada como uma constante transhistórica que delimita o local dessa temporalização: ao contrário de examinarem a segmentação em relação a outras unidades do sistema internacional como "natural" ou "dada", os autores salientam que a resposta hierarquizante e disciplinadora à diferença domesticamente transbordou para seu tratamento na esfera externa e, no processo dinâmico de relações interculturais, figurou tal diferença como uma ameaça constante interditada nas fronteiras, enfrentada militarmente ou colonizada. A defesa das fronteiras externas visa a preservar a diferença fora dos limites estatais, de forma que a tolerância entre tais unidades políticas no nível internacional procede do equilíbrio de poder e não do reconhecimento genuíno da diversidade. Nesse sentido, simultaneamente à temporalização, Blaney e Inayatullah caminham também no sentido da desnaturalização do Estado: a segmentação entre "dentro" e "fora" constitutiva da "sociedade de estados" - que consolida as delimitações geopolíticas como receptáculos espaciais da diversidade cultural e mantém-nos reféns do entendimento depreciativo da diferença - opera como pré-requisito para o adiamento do "problema da diferença” e a diluição de oportunidades para maior engajamento com a diversidade, desvelando a operação de um processo de homogeneização cultural sistemática acompanhado da constituição uniformizadora das unidades políticas na dimensão internacional (BLANEY \& INAYATULLAH, 2004, p. 44-45).

Além da problematização das estratégias temporais de emprego das noções de desenvolvimento e modernização - que cristalizam a diferença como "atraso" -, tal releitura crítica da construção da área pauta-se no questionamento da concepção convencional da Paz de Vestfália como marco de transição para uma modernidade mais tolerante e na ênfase à influência deletéria da Guerra dos Trinta Anos no discurso intelectual 
sobre a diferença, administrada a partir de estratégias espaciais de segmentação. Em nível teórico, Blaney e Inayatullah (idem, p. 93-125) evidenciam que a repulsa ao reconhecimento de oportunidades de tratamento da diferença como recurso potencial - sendo inclusive vedado a ela status ontológico independente - é revigorada por teorias de neomodernização como as abordagens do mainstream das Relações Internacionais, que naturalizam as delimitações espaciais de dentro/ fora - cristalizando a tensão entre ordem e anarquia e protelando a resolução do "problema da diferença” ao tentar circunscrevê-la dentro dos estados - e essencializam a seqüência de tradição/ modernidade, espacializando o tempo e situando a diferença ao longo do espaço em "estágios de desenvolvimento". Tal crítica elucida que o impulso homogeneizante dessas teorias opera numa lógica comparativa que forja uma uniformidade relativa dos sistemas políticos e desenvolve esquemas classificatórios espaçotemporais hierarquizantes. A visão liberal de soberania é universalizada por tais teorias, que estabelecem padrões generalizáveis como a concepção de estados como "unidades funcionalmente semelhantes” e assumem uma interpretação linear do tempo.

Demonstrando a forma como a teoria e a prática cristalizam a integridade do "império da uniformidade” doméstico num impulso dominante de localização da diversidade como ameaça, Blaney e Inayatullah (idem, p. 203-204; 215-217) reconsideram o papel da diferença na constituição da área de Relações Internacionais a partir da exploração do contra-impulso de regeneração e apreciação da diversidade como meio de autoreflexão e crítica social. A proposta para uma perspectiva etnológica da "política de comparação" como um entendimento mais holístico da diferença - definindo espaços de conexão e diálogo entre o Eu e os Outros externo e interno, que evidenciam a especificidade histórico-cultural dos entendimentos - relativiza categorias e permite pensar "formas mistas" de arranjos do espaço global que reconheçam a heterogeneidade e a coexistência das múltiplas práticas políticoculturais. Tal esforço complexo de criação e negociação de autoridades compartilhadas e sobrepostas desestabiliza a noção de espaço estatal homogêneo, absoluto e rigidamente segmentado tanto em relação à sociedade civil como às demais unidades no sistema internacional.
Superando a marginalização da cultura e a despersonalização da área de Relações Internacionais e questionando a limitação de sua matéria-prima ao formalmente político, a abordagem crítica de Darby (1998) propõe uma concepção ainda mais ampla da disciplina ao explorar a ênfase da literatura na dimensão pessoal e a relevância da narrativa ficcional no engajamento cultural entre o local, o civilizacional e o global. Com tal iniciativa, procura encorajar novos corpos de conhecimento que transcendam a rigidez das linhas de demarcação e problematizar os pressupostos mecanicistas da teorização dominante em Relações Internacionais, que concede privilégios ao centro e subestima a agência de povos subordinados. Ao apontar que os encontros coloniais envolvem ambivalência do colonizador e do colonizado e que podem existir momentos de cumplicidade com a diferença localizada dentro e fora, a orientação pessoal e cultural da literatura desestabiliza segmentações internas e externas que reificam o Estado e viabiliza a contínua redefinição do entendimento do político.

Tendo em vista que a política adquire seu sentido a partir da cultura, a obra artística tornase um repositório desse entendimento e, numa perspectiva inclusiva das múltiplas facetas da vida humana, contextualiza à vida cotidiana a política, em vez de concebê-la como uma esfera autônoma de ação e pensamento. As experiências dos indivíduos são contadas ao longo das do seu grupo, e, como os sistemas de troca são mediados pela experiência vivida, o mundo exterior - por exemplo, a dimensão da interação internacional é concebido em relação ao interior sociocultural, pessoal e subjetivo, que abarca formas de comportamento e emoções. A personalização das questões direciona a atenção para condições mutáveis que estabelecem padrões de interação social, e a literatura viabiliza a integração entre o moral e o político, promovendo a reavaliação de sensibilidades e valores. Ao reconceituarem o imperialismo, narrativas ficcionais evidenciam a vulnerabilidade e a transitoriedade da supremacia ocidental e salientam contra-movimentos que introduzem perspectivas de mudança. Ademais, explicitam que as linhas divisórias que conduzem à dominação e ao absolutismo moral na rejeição do Outro são traçadas para proteção em relação à insegurança, particularmente em face do desejo em relação ao Outro pelos seus elementos de diferença e sua similaridade com tempos passados (idem, p. 46-50, 71-73, 220-234). 
Ao considerar que a área despersonalizou-se com o enfoque em atores monolíticos extraídos do contexto humano e que a cultura não apenas afeta o comportamento dos estados mas está ligada à transformação social, Darby desnaturaliza divisões rígidas que localizam espacialmente a diferença no exterior e consegue, a partir da consideração das obras literárias, verificar o estabelecimento de áreas de congruência, acomodação, contato cultural e sobreposição de medos e esperanças entre a identidade e a diferença. A maior inclinação ao engajamento emocional pela literatura explicita que idéias e processos são realizados no comportamento de indivíduos e grupos. A sensibilidade moral pode estimular a reconfiguração do pensamento, dirigindo-se o foco do Estado para a subjetividade da experiência vivida por indivíduos situados em contextos de intercâmbio cultural e de negociação com a diferença, os quais se relacionam a aspectos das relações intersociais e da política internacional, e, com isso, a questões morais integradas à política. A redefinição do conceito de Relações Internacionais opera a partir do desafio às concepções "estatocêntricas” e etnocêntricas da disciplina, compreendidas como frutos da fixação da área com o poder como elemento definidor da política mundial e do descaso com relação a desenvolvimentos internos das sociedades do Terceiro Mundo, que poderiam afetar a dinâmica de engajamento com o Norte e o sistema internacional (idem, p. 9-19, 39-42).

Simultaneamente à problematização da concepção dada e reificada de segmentação externa que cristaliza o Estado, Darby (idem, p. 55-56, 71-73) elucida momentos de cumplicidade e intimidade com a diferença localizada dentro da comunidade sociopolítica. A partir disso, a insegurança, a dúvida e o temor em relação à diferença que opera fora das regras de engajamento estipuladas também internamente são trazidos à tona pela ficção e configuram-se como limites ao exercício efetivo do poder e da autoridade de lideranças estatais sobre os indivíduos. Nesse sentido, o autor aponta concomitantemente rumo à temporalização, num momento em que a dificuldade no tratamento da diferença traz desafios à estrutura do poder vigente e subversões às noções cristalizadoras de política, que pressupõem a negação do Outro interior, a marginalização do discurso do Outro e a perpetuação de uma concepção auto-referencial do exercício do poder nos âmbitos doméstico e internacional. Indo-se além da consideração de atributos materiais e manifestações externas, a releitura da dominância a partir desse procedimento comprova que existem traços de cultura compartilhada entre as partes os quais expõem a ambivalência da relação entre dominador e dominado - e reforça-se o papel alegórico das categorias derivadas do comportamento interpessoal para a sondagem do político, de forma a evidenciar que o pessoal é político ou representa a extensão dele: o sentido do poder não pode ser desvinculado do pensamento daqueles que o exercem e dos que o experimentam.

Já Shapiro (2004) avança ainda mais no questionamento ao problematizar conceitos de construção e manutenção dos estados-nação e métodos de formação de nações culturalmente coesas, além de promover o reconhecimento de mecanismos de expressão política alternativos às práticas estatais de criação das culturas nacionais. $\mathrm{O}$ autor não somente contraria modelos referenciais do real empregados por uma ciência supostamente "não-tendenciosa" e a concepção monológica e universalizante do sujeito de conhecimento, como salienta a operação de interações semióticas entre indivíduos que aplicam múltiplos meios de produção de significado e assumem diferentes perspectivas sobre elementos envolvidos no entendimento. Shapiro também oferece um tratamento complexo à linguagem: transcendendo a mera relação entre declarações e referentes, a perspectiva semiológica proposta considera sistemas de significado como produtores - não apenas referenciais - e examina a inteligibilidade inter-relacionalmente num sistema simbólico. Elucida-se, assim, como perspectivas culturais particulares apontam para a imposição de ordens de significado às custas de outras. A partir de uma perspectiva foucaultiana, Shapiro desvela que discursos de conhecimento sobre "razão" ou "verdade” não remetem a noções subjacentes ou fundacionais, mas são gerados como exercícios de controle em circunstâncias históricas específicas. O poder implicado nos sistemas de conhecimento compõe novos objetos discursivos e locações privilegiadas a partir das quais é possível a expressão legítima e inteligível e é examinado no seu caráter relacional, sendo que tal poder estende-se inclusive ao corpo do indivíduo, investido por relações de dominação. 
A partir desse ponto, Shapiro permite avançar na direção da temporalização do Estado, pois, ao ampliar a esfera de subjetivação e não assumir uma retórica despolitizante da diferença, rejeita a padronização e, ao enfocar a dinâmica de encontros históricos entre perspectivas distintas de produção de significado, oferece uma interpretação que desafia a autoridade do local de enunciação dominante e proporciona a autoreflexão a partir da consideração de incoerências e alteridades nas práticas de inteligibilidade. Tal procedimento expõe não apenas a distância entre linguagem e o mundo de referência, mas os projetos silenciadores de múltiplas vozes numa política totalizante contida nas culturas unitárias nacionais, forjadas por um sistema único de significado. Memórias contestadoras da produção estatal revelam que a nação não é homogênea ou fundacional e que as segmentações internas que fortalecem o Estado como locus de autoridade são instáveis: em nível histórico, como o controle dos estados-nação sobre espaços e corpos foi gradualmente problematizado, sua autoridade mostra-se interpretativa e performática, de forma que eles "atuam” visando à preservação de seu status ontológico e prático (idem, p. XI-XVII).

Shapiro observa que os aspectos coercitivos e econômicos de controle estatal foram complementados pelo gerenciamento de disposições e significados dos corpos dos cidadãos com o objetivo de compatibilizar fronteiras territoriais e culturais; contudo, as práticas materiais e interpretativas que sustentam metafisicamente os estados-nação são desafiadas, de forma que as nações são concebidas como processos contenciosos historicamente específicos, os quais garantem sua permanência simbólica a partir de práticas institucionalizadas. A arbitrariedade na busca de fundações espaçotemporais para a nacionalidade torna-se evidente na instabilidade do processo de construção nacional: produções culturais nativas ressaltam “geografias de identidade" locais em vez de nacionais e revelam a incompletude da integração nacional pela "máquina de captura" estatal, que tenta espacializar o tempo para estabilizar sua existência como receptáculo desse tempo - onde não há Estado, não há tempo, e, conseqüentemente, não há história ou perspectiva de futuro. Shapiro viabiliza a problematização de segmentações internas que fortalecem o Estado e evidencia que o espaço doméstico é heterogêneo e as demarcações entre Estado e sociedade civil são mutáveis. O poder não é mais concebido de forma essencializada em termos do comando e da obediência à autoridade soberana, mas de práticas múltiplas que revelam a operação de novas vozes contestadoras (idem, p. 33-67).

Simultaneamente na obra de Shapiro, transcendendo-se uma concepção limitada de governança como simples gerenciamento de pessoas num território, a mobilização de múltiplos modos de governança cultural como complementos de monopólios coercitivos é compreendida como um processo histórico de imposição de fronteiras e hierarquização de povos em níveis distintos de coesão cultural, resultantes do exercício de poder. Além disso, Shapiro destaca que o conceito de biopoder envolve uma dimensão expansionista e militante, de forma que o Estado de segurança moderno, visando a proteger sua população, tem gradualmente percebido a necessidade de conter ameaças no nível internacional. Nesse sentido, em vez de oferecer um tratamento não-problematizado às divisões entre Estado e sistema internacional, Shapiro caminha na direção da desnaturalização num momento em que verifica que as delimitações estatais não são dadas ou estagnadas, mas artifícios flexíveis que preenchem uma ambição reguladora. Em seu processo de expansão, a soberania imperial envolve não apenas uma militarização expansionista e uma biopolítica de vigilância da diferença também localizada fora do Estado, mas o apoio a múltiplos gêneros de expressão que podem ser mobilizados a fim de garantir essas práticas e inibir aquelas que apontam na direção contrária. Diante da falta de antagonistas facilmente discerníveis, a representação da ameaça assume uma dimensão expansiva, de forma que escolhas violentas são feitas a fim de defender-se uma humanidade politicamente qualificada, e as distinções entre a luta contra ameaças criminalizadas na dimensão doméstica e o aparato de guerra global vêm sendo paulatinamente diluídas, já que a soberania opera num processo de estabelecimento de exceções para o uso de força extralegal (idem, p. 177-182).

Além da consideração histórica da diversidade de locais de enunciação de vozes definidoras do status do Estado-nação, Shapiro (idem, p. 26-31) busca uma abordagem teórica alternativa que viabilize a crítica à trajetória de discursos políticos “estatocêntricos” e eurocêntricos sobre a construção nacional, evidenciando que a ciência 
política geo-historicamente localizada ofereceu uma série de veículos conceituais para a normalização do espaço estatal e limitou o escopo de perspectivas de entendimento de mundo. Tal abordagem também procura trazer desafios aos efeitos despolitizantes e legitimadores da perspectiva liberal sobre igualdade. Seus méritos são elucidar a resistência à homogeneização estatal e revelar que o conhecimento é fruto da dinâmica interação de perspectivas em constante transformação, não de circunstâncias essencializadas nas fronteiras reificadas do Estadonação. Ao situar-se a produção de conhecimento no centro da análise histórico-política sem apartála da produção de poder, a ênfase na resistência à inscrição de corpos em ordens semióticas impostas por uma autoridade centralizadora e no desafio às tentativas de homogeneização permite problematizar a suposta naturalidade das práticas que as viabilizaram. Tal atitude interpretativa não somente identifica como as práticas de poder são criadas e consolidadas, mas desconstrói as concepções deterministas de sociedade e evidencia quão arbitrárias são as estruturas reificadoras que marcam o pensamento.

\section{CONCLUSÕES}

O Estado preservou uma autoridade simbólica pelo seu questionamento sistemático no discurso; porém, a condução simultânea dos procedimentos de desnaturalização e temporalização permite desreificar as segmentações que cristalizam o status ontológico e prático do Estado e desenvolver uma nova concepção do político. Transcendendo os esforços de categorização imutável de autores em "reificadores” ou "não-reificadores do Estado" e a assimilação de versões simplificadas ou estereotipadas de suas obras, a abordagem aqui desenvolvida demonstrou que, enquanto grande parte da produção na teoria de Relações Internacionais tem reafirmado a centralidade do Estado na imaginação política e limitado o pensamento sobre alternativas além dele, novos caminhos teóricos abertos que desestabilizem concomitantemente as divisões entre Estado e sistema internacional e Estado e sociedade civil permitem a identificação das incoerências e das ambivalências nas práticas dos estados, o questionamento de seu poder sobre os indivíduos e a consideração de formas alternativas de organizar-se o espaço, problematizando as noções de segmentação rígida e absoluta e concebendo a diversidade como meio de crítica social e de auto- reflexão.

Em termos analíticos e práticos, Blaney e Inayatullah (2004) ofereceram um passo importante nessa direção ao problematizarem as divisões internas e externas que conduzem à centralidade do conceito de Estado. A concepção do Outro interno que não foi absorto pela homogeneização cultural desafia a autoridade performática do Estado sobre os atores sociais. Ademais, o engajamento com as experiências dos Outros externos tanto na prática política como na própria produção do conhecimento sobre a diferença pode conduzir a uma desestabilização da fixidez das fronteiras externas que marginalizam e hierarquizam a diversidade. Com o entendimento alternativo das "zonas de contato" entre o Eu e o Outro, torna-se possível a autocrítica e o aprendizado com as experiências de outras sociedades, o que pode culminar em novas formas de organização do espaço alternativas ao Estado. Já Darby (1998) também sinaliza nessa direção ao desessencializar as demarcações internas que cristalizam o Estado, focalizar os desvios às regras de interação estabelecidas para o relacionamento entre Estado e forças sociais e, ao mesmo tempo, problematizar segmentações externas ressaltando a cultura simbiótica entre colonizador e colonizado e o hibridismo.

Ao conceber o Estado-nação como um ator biopolítico que traduz o corpo biológico como social, Shapiro (2004) traz à tona a forma como o aparato estatal tenta aprisionar esses corpos, revelando o processo historicamente específico de produção de homogeneidade e coesão cultural etnonacional. Nesse processo, um dos méritos de sua abordagem é desvelar que obras de arte produzidas fora da "máquina de captura" da governança cultural estatal elaboraram formas alternativas de adesão e colocam em xeque a uniformidade das culturas nacionais e a fixidez dos processos voltados para a relação entre Estado e sociedade civil. Ao mesmo tempo, Shapiro desnaturaliza o Estado ressaltando que o biopoder expande-se num processo de preservação em relação a ameaças ao Estado advindas do sistema internacional. Com isso, ele questiona o caráter supostamente essencial de segmentações entre Estado e sistema internacional, vendo que elas são maleáveis e que cristalizam a diversidade como uma anomalia ou uma disfunção. Esta abordagem, bem como as de Blaney e Inayatullah e de Darby, 
são apenas algumas alternativas de pensarem-se caminhos para uma teorização que vá além do Estado. Em vez de estabelecer uma direção única para esse empreendimento, tais abordagens apenas apontam questões relevantes que nos oferecem pelo menos a possibilidade de dar um primeiro passo na direção de um pensamento político mais crítico e emancipatório.

Diego Santos Vieira de Jesus (dsvj1408@terra.com.br) é Mestre em Relações Internacionais pela Pontifícia Universidade Católica do Rio de Janeiro (PUC-RJ) e Professor de Relações Internacionais da mesma instituição.

\section{REFERÊNCIAS BIBLIOGRÁFICAS}

ASHLEY, R. 1987. The Geopolitics of Geopolitical Space : Toward a Critical Social Theory of International Politics. Alternatives, Toronto, n. XII, p. 403-434.

BARTELSON, J. 1998. Second Natures : Is the State Identical With Itself ? European Journal of International Relations, Exeter, v. 4, n. 3, p. 295-326.

2001. The Critique of the State. Cambridge : Cambridge University.

BLANEY, D. L. \& INAYATULLAH, N. 2004. International Relations and the Problem of Difference. New York : Routledge.

CAMARGO, S. 2004. Quo vadis, Europa? Uma pergunta que não quer calar. Contexto Internacional, Rio de Janeiro, v. 26, n. 1, p. 65-103.

COX, R. 1986. Social Forces, States and World Orders : Beyond International Relations Theory. In : KEOHANE, R. (org.). Neorealism and its Critics. New York : Columbia University.

1993. Gramsci, Hegemony and International Relations : An Essay on Method. In : GILL, S. (ed.) Gramsci, Historical Materialism and International Relations. Cambridge : Cambridge University.

DARBY, P. 1998. The Fiction of Imperialism : Reading Between International Relations and Postcolonialism. London : Cassell.

GOUREVITCH, P. A. 1999. Robert O. Keohane : The Study of International Relations. Political Science \& Politics, Cambridge, v. 7, n. 2, Sept.

GRIECO, J. 1997. Realist International Theory and the Study of World Politics. In : DOYLE, M. W. \& IKENBERRY, G. J. (eds). New
Thinking in International Relations Theory. Boulder : Westview.

HERZ, M. \& HOFFMANN, A. R. 2004 Integração regional. In : HERZ, M. \& HOFFMANN. Organizações Internacionais : história e práticas. Rio de Janeiro : Campus.

HURRELL, A. 1995. O ressurgimento do regionalismo na política mundial. Contexto Internacional, Rio de Janeiro, v. 17, n. 1, p. 23-59.

KAHLER, M. 1997. Inventing International Relations : International Relations Theory After 1945. In : DOYLE, M. W. \& IKENBERRY, G. J. (eds). New Thinking in International Relations Theory. Boulder : Westview.

KATZENSTEIN, P. J.; KEOHANE, R. O. \& KRASNER, S. D. 1998. International Organization and the Study of World Politics. International Organization, Cambridge, Mass., v. 52, n. 4, p. 645-686. Disponível em : http:/ /www.irchina.org/Katzenstein/KKK1998.pdf. Acesso em : 14.jan.2009.

KELSTRUP, M. 1998. Integration Theories : History, Competing Approaches and New Perspectives. In : WIVEL, A. (ed.). Explaining European Integration. Copenhagen : Copenhagen Political.

KEOHANE, R. O. 1986. Theory of World Politics : Structural Realism and Beyond. In : KEOHANE. (org.). Neorealism and its Critics. New York : Columbia University.

KEOHANE, R. O. \& NYE, J. S. 1977. Power and Interdependence : World Politics in Transition. Boston : Little, Brown.

LEBOW, R. N. 2007. The Future of International Relations Theory. In : LEBOW. Coercion, 
Cooperation and Ethics in International Relations. New York : Routledge.

ROSE, N. \& MILLER, P. 1992. Political Power Beyond the State : Problematics of Government. British Journal of Sociology, London, v. 43, n. 2, p. 173-205. Disponível em : http://www.lse.ac.uk/collections/ s o c i o l o g y / p d f / R o s e Politicalpowerbeyondthestate-BJS1991.pdf Acesso em : 14.jan.2009.

SHAPIRO, M. 2004. Methods and Nations : Cultural Governance and the Indigenous Subject. New York : Routledge.

SNYDER, R. C.; BRUCK, H. W. \& SAPIN, B. 1961. The Decision-Making Approach to the Study of International Politics. In : ROSENAU, J. N. (ed.). International Politics and Foreign Policy. New York : Free Press.

WALKER, R. B. J. 1993. Inside/Outside : International Relations as Political Theory.
Cambridge : Cambridge University.

2005. The Doubled Outsides of the Modern International. Lecture presented at the Fifth International Conference on Diversity in Organizations, Communities and Nations, Central Institute of Ethnic Administrators, Beijing, June 30-July 3. Disponível em : http:/ /web.uvic.ca/polisci/walker/onlinepapers/ rbjdoubledoutsides.pdf Acesso em : 14.jan.2009.

WALTZ, K. N. 1979. Theory of International Politics. Reading, Mass. : Addison-Wesley.

WENDT, A. 1992. Anarchy is What States Make of it : The Social Construction of Power Politics. International Organization, Cambridge, Mass., v. 46, n. 2, p. 391-425. Disponível em : http://web.pdx.edu/ kinsella/ ps442/wendt.pdf Acesso em : 14.jan.2009.

1999. Social Theory of International Politics. Cambridge : Cambridge University. 
VERS UNE THÉORIE AU-DELÀ DE L’ÉTAT: LA DOUBLE DÉMARCHE DE DÉNATURALISATION ET TEMPORALISATION

\section{Diego Santos Vieira de Jesus}

L'article a pour objectif non seulement d'expliquer pourquoi une double démarche de dénaturalisation et temporalisation favorise un premier pas vers une théorie envisageant la dissolution des notions d'autorité et d'identité du concept d'État et la redéfinition du problème de l'ordre politique international, mais encore d'identifier, dans les débats récents de la théorie politique et de la théorie de Relations Internationales, des approches alternatives allant vers cette double démarche. L'hypothèse centrale dont la justesse on envisage de vérifier est que la double démarche de dénaturalisation et temporalisation permet l'affaiblissement en simultanée des segments internes qui confortent l'État et qui le distinguent comme locus d'autoritié opposé à des forces apolitiques de la société domestique et des divisions externes qui le différencient des organisations internationales similaires. A partir de ce manque de stabilité, on met en question les interprétations étatiques de l'autorité et on redéfinit les débats sur l'ordre politique international, tout en générant de nouvelles matrices et en renouvelant l'entendement du politique : non seulement des organisations alternatives de l'espace peuvent être considérées à partir de l'appréciation de la différence comme moyen d'auto-reflexion et de critique sociale, mais aussi on peut admettre des perpectives envisageant des incohérences et ambigüités des pratiques étatiques et mettant en question le contrôle de l’État sur des espaces et des corps à la recherche de préservation de leur statut ontologique et pratique.

MOTS-CLÉS : Théorie Politique ; théorie des Relations Internationales ; théorie post-moderne ; État ; dénaturalisation ; temporalisation.

NOUVEAUX LEADERS SUD-AMÉRICAINS: CLIVAGE SUR LE BINÔME STABILITÉINSTABILITÉ POLITIQUE

\section{Rafael Duarte Villa}

L'article traite de l’instabilité politique en Amérique latine, surtout au Brésil et dans les pays composant la Région Andine et le Cône Sud. Nous étudions les causes de l'apparition des nouveaux leaders politiques dans ces pays et leur rapport aux situations de stabilité ou d'instabilité politiques. L'article défend que l'avènement de nouveaux leaders en Amérique latine, qui ont émergé dans un contexte de stabilité et instabilité politique, ne peut être compris seulement par des hypothèses mettant en relief les caractéristiques populaires ou les défaillances de la modernisation politique, vu que la casuistique plus profonde de cette émergence devrait être cherchée dans de nouveaux clivages d'identité éthnique et sociale ainsi que d'un nouveau modèle de rapport entre mouvements sociaux et nouveaux leaders. Nous concluons que l'ascension des nouveaux leaders politiques dans les pays analysés est souvent liée à une crise de légitimité du système politique. Nous assumons aussi que le « néo-populisme » peut être une variable explicative de l'émergence de nouveaux acteurs dans des contextes d'instabilité politique, à condition que cette variable ne soit pas descontextualisée.

MOTS-CLÉS : élite politique ; néo-populisme ; Région Andine ; instabilité politique ; légitimité politique ; économicisme. 
TOWARD THEORIZING BEYOND THE STATE: THE TWO-FOLD PROCEDURE OF DENATURALIZATION AND PROVIDING TEMPORALITY

\section{Diego Santos Vieira de Jesus}

This purpose of this article is to explain why a two fold procedure of denaturalization and providing temporality offers the first step toward a new type of theorizing. We refer to the dissolution of notions of authority and identity of the State and the re-definition of the problem of the international political order, as well as identifying alternative approaches that pursue the course offered by this two-fold procedure within recent debates on political theory and theories of international relations. The central hypothesis whose correctness we intend to verify here is that this twofold procedure of denaturalization and providing temporality (time-boundedness) allows the simultaneous destabilization of the internal segments that strengthen the State and differentiate it as a locus of authority counterposed to apolitical forces of domestic society and of the external divisions that distinguish it from similar international entities. Through this destabilization, Statist interpretations of authority are problematized and discussions on the international political order are re-defined, creating new matrixes and renewing our understanding of the political. Alternative forms of organizing space can thereby be thought up, on the basis of appreciation of difference as a means for self-reflection and social critique, and perspectives that consider the inconsistencies and ambivalence of State practices and that question State control over spaces and bodies, in favor of the preservation of their ontological and practical status, can be developed.

KEYWORDS: Political Theory; International Relations Theory; Post-modern Theory; State; denaturalization; temporalization.

\section{NEW SOUTH AMERICAN LEADERSHIP: CLEAVAGES IN THE STABILITY-INSTABILITY} BINOMY

Rafael Duarte Villa

This article looks at political instability in Latin America, particularly for the countries that make up the Andean region, the Southern Cone and Brazil. We inquire into the causes behind the emergence of new political leadership in these countries and the relationship that such leadership has with situations of political stability or instability. We sustain that the emergence of new leadership in Latin America, which has emerged within a dynamic of political stability and instability cannot be understood solely through hypotheses that give salience to populist traits or flaws in processes of political modernization. Rather, deeper causal explanation for the appearance of such new leadership should be sought in the new cleavages that demonstrate the renovation of elite groups, as well as the emergence of ethnic and social divisions and of new patterns of relationship between social movements and new leadership. We conclude that the rise of new political leadership in the countries that we analyze is generally linked to a legitimacy crisis within the political system. We also hold that "neo-populism" may be an explanatory variable for the emergence of new actors in contexts of political instability, but care must be taken to give adequate emphasis to contextual factors.

KEYWORDS: political elite; neo-populism; Andean region; political instability; political legitimacy; economicism. 